\title{
EFISIENSI PENEGAKAN HUKUM TERHADAP TINDAK PIDANA PERINDUSTRIAN ME MPRODUKSI BARANG YANG TIDAK MEMENUHI STANDAR NASIONAL INDONESIA
}

\author{
Wuryanti \\ Email :wuryanti28@gmail.com \\ Mahasis wa Program Magister Ilmu Hukum, Program Pascasarjana \\ Fakultas Hukum Universitas Sebelas Maret Surakarta \\ Hari Purwadi \\ Email: h purwadie@yahoo.com \\ Dosen Fakultas Hukum Universitas Sebelas Maret Surakarta
}

\begin{abstract}
This article examines what criminal policy chosen at each stage of law enforcement against criminal acts industrial production of goods that do not meet the Indonesian National Standards mandatory and how the efficiency of law enforcement against criminal acts of industry in realizing social welfare. This research is an interdisciplinary law with the assumption (paradigm) legal research is not just seen as the rules / norms but also as a value containing economic calculations. The nature of the research is descriptive research with a form of evaluative research. The approach uses qualitative research approach with the data source library materials in the field of law that is the primary legal materials, legal materials secondary and tertiary legal materials. Data collection techniques in this study using library research (literature study) and study the documentation. Data processing techniques in this study the data obtained is presented qualitatively then be analyzed using descriptive analysis. And data analysis techniques in the study of data reduction, data presentation and conclusion. The result of that criminal policy in law enforcement against criminal acts that violate the provisions of $\mathrm{SNI}$ started in the formation of legislation by the legislature, At the level of investigation and prosecution were carried out by investigators, police investigators and prosecutors of the Attorney as the authority of state government (executive), criminal policy in law enforcement against criminal acts that violate the provisions of SNI no special policies. The criminal policy of judicial power which is run by the Supreme Court and judicial bodies underneath, reflected in the verdicts handed down for criminal acts that violate the provisions of SNI. The efficiency of law enforcement against criminal acts that violate the provisions of SNI can be done in three (3) aspects of function invocations ultimum remedium criminal law, proof materially application for the goods and / or services are subjected to compulsory S NI and the imposition of criminal optimal.
\end{abstract}

Key word : efficiency, law enforcement, $S N I$

\begin{abstract}
Abstrak
Tulisan ini mengkaji apa kebijakan kriminal yang dipilih pada setiap tahapan penegakan hukum terhadap tindak pidana perindustrian memproduksi barang yang tidak memenuhi Standar Nasional Indonesia wajib dan bagaimana efisiensi penegakan hukum terhadap tindak pidana perindustrian dalam mewujudkan kesejahteraan sosial masyarakat. Penelitian ini adalah penelitian hukum interdisiplin dengan asumsi (paradigma) penelitian hukum tidak hanya dilihat sebagai aturan/norma tetapi juga sebagai nilai yang mengandung kalkulasi ekonomi.Sifat penelitian yang digunakan adalah penelitian deskriptif dengan bentuk penelitian evaluative.Pendekatannya menggunakan pendekatan penelitian kualitatif dengan sumber data bahan pustaka di bidang hukum yakni bahan hukum primair, bahan hukum skunder dan bahan hukum tersier.Teknik pengumpulan data dalam penelitian ini menggunakan library research (studi kepustakaan) dan studi dokumentasi. Teknik pengolaan data dalam penelitian ini data yang diperoleh disajikan secara kualitatif kemudian akan dianalisis dengan menggunakan analisis diskriptif. Dan teknik analisis data dalam penelitian ini yaitu reduksi data, penyajian data dan penarikan kesimpulan. Hasil bahwa Kebijakan kriminal dalam penegakan hukum terhadap tindak pidana yang melanggar ketentuan SNI wajib dimulai dari tingkat pembentukan undang-undang oleh lembaga legislatif, $\mathrm{Di}$ tingkat penyidikan dan penuntutan yang dilaksanakan oleh PP NS, Penyidik Polri, dan PenuntutU mum pada Kejaksaan R I sebagai kekuasaan pemerintahan negara (eksekutif), kebijakan kriminal dalam penegakan hukum terhadap tindak pidana yang
\end{abstract}


melanggar ketentuan SNI wajib tidak ada kebijakan khusus. Kebijakan kriminal kekuasaan kehakiman yang dijalankan oleh Mahkamah Agung RI dan badan peradilan di bawahnya, tercermin dari putusanputusan yang dijatuhkan atas tindak pidana yang melanggar ketentuan SNI wajib.Efisiensi penegakan hukum terhadap tindak pidana yang melanggar ketentuan SNI wajib dapat dilakukan dalam 3 (tiga) aspek yaitu penjalanan fungsi ultimum remedium hukum pidana, penerapan pembuktian secara materiil atas barang dan/atau jasa yang diberlakukan SNI wajib dan penjatuhan pidana yang optimal.

Kata kunci : efisiensi, penegakan hukum, SNI

\section{A. Pendahuluan}

Efek dari berkembangnya era globalisasi, perekonomian suatu negara akan semakin terintegrasi dengan negara lain, baik dalam suatu kawasan maupun dunia pada umumnya. Upaya pertama Indonesia dalam persiapan menghadapi era globalisasi sebagaimana disebutkan di atas adalah penguatan daya saing ekonomi.Hal ini merupakan perwujudan dari upaya melindungi segenap bangsa Indonesia dan memajukan kesejahteraan umum. Salah satu cara untuk penguatan daya saing ekonomi adalah dengan melakukan standarisasi industri yang diselenggarakan dalam wujud Standar Nasional Indonesia (SNI), spesifikasi teknis, dan/ atau pedoman tata cara yang berlaku di seluruh wilayah Negara Kesatuan Republik Indonesia, sebagaimana di jelaskan dalam Pasal 50 Undang-Undang Nomor 3 Tahun 2014 Tentang Perindustrian.

Penerapan S NI oleh Perusahaan Industri pada dasarnya bersifat sukarela, namun pemerintah dapat menetapkan pemberlakuan SNI secara wajib terhadap barang dan/atau J asa Industri yang telah ditetapkan, yang dilakukan untuk: a. keamanan, kesehatan, dan keselamatan manusia, hewan, dan tumbuhan, b. pelestarian fungsi lingkungan hidup, c. persaingan usaha yang sehat, d. peningkatan daya saing, dan/ atau, e. peningkatan efisiensi dan kinerja industri. Selain sebagai upaya perlindungan terhadap industri, pemberlakuan SNI ini sekaligus untuk perlindungan terhadap konsumen pengguna produk.

Agar dapat efektif mencapai tujuan, upaya peningkatan daya saing ekonomi dengan standarisasi industri juga harus sejalan dengan upaya lainnya yaitu upaya penguatan sektor Usaha Kecil dan Menengah (UMKM), perbaikan infrastruktur, peningkatan kualitas Sumber Daya Manusia, dan reformasi kelembagaan dan pemerintahan.Ketidakselarasan antara kelima upaya tersebut, justru dapat menghambat persiapan Indonesia dalam menghadapi pasar bebas. Hal ini terjadi dalam perkara Nomor 169/Pid.Sus/2015/PN Krg di Pengadilan Negeri Karanganyar dengan Terdakwa Muhammad Kusrin, sehingga Terdakwa diajukan ke persidangan dengan dakwaan melakukan perbuatan sebagaimana diatur dan diancam pidana dalam Pasal 120 Ayat (1) jo. Pasal 53 Ayat (1) huruf b Undang-undang RI Nomor 3 Tahun 2014 tentang Perindustrian.

Secara normatif penegakan hukum mulai dari penyidikan, penuntutan dan pengadilan dalam perkara a quo tidak keliru, namun jika dikaitkan dengan sistem hukum secara keseluruhan, dan tujuan dari diberlakukannya hukum tersebut, justeru menjadi tidak efisien dan dapat menghambat upaya persiapan menghadapi pasar bebas. Hal ini menjadi menarik untuk dikaji, khususnya dari kacamata analisis ekonomi terhadap hukum, karena dalam hal ini permasalahan ekonomi berkelindan dengan masalah hukum.Sebagaimana dikatakan oleh Abdul Manan, bahwa hubungan hukum dengan ekonomi bukan hubungan satu arah, tetapi hubungan timbal-balik dan saling mempengaruhi.

Berdasarkan paradigma tersebut diatas, maka dalam tulisan ini hendak dikaji :Apa kebijakan kriminal yang dipilih pada setiap tahapan penegakan hukum terhadap tindak pidana perindustrian yang melanggar ketentuan Standar Nasional Indonesia (SNI) wajib?dan bagaimanakah efisiensi penegakan hukum terhadap tindak pidana perindustrian dalam mewujudkan kesejahteraan sosial masyarakat?

\section{B. Metode Penelitian}

Penelitian ini adalah penelitian hukum normative interdisiplin dengan asumsi (paradigma) penelitian hukum tidak hanya dilihat sebagai aturan/norma tetapi juga sebagai nilai yang mengandung kalkulasi ekonomi Sifat penelitian yang digunakan adalah penelitian deskriptif dengan bentuk penelitian evaluative.Pendekatannya menggunakan pendekatan penelitian kualitatif dengan sumber data bahan pustaka di bidang 
hukum yakni bahan hukum primair, bahan hukum skunder dan bahan hukum tersier. Teknik pengumpulan data dalam penelitian ini menggunakan library research (studi kepustakaan) dan studi dokumentasi. Teknik pengolaan data dalam penelitian ini data yang diperoleh disajikan secara kualitatif kemudian akan dianalisis dengan menggunakan analisis diskriptif. Dan Teknik analisis data dalam penelitian ini yaitu reduksi data, penyajian data dan penarikan kesimpulan.

\section{Hasil Penelitiandan Pembahasan}

1. Kebijakan Kriminal yang Dipilih Pada Setiap Tahapan Penegakan Hukum Terhadap Tindak Pidana Perindustrian yang Melanggar Ketentuan Standar Nasional Indonesia (SNI) wajib.

Definisi Kebijakan Kriminal Menurut Sudartoada tiga yaitu: Dalam arti sempit, adalah keseluruhan asas dan metode yang menjadi dasar dari reaksi terhadap pelanggaran hukum yang berupa pidana, dalam arti luas adalah keseluruhan fungsi dari aparatur penegak hukum, termasuk di dalamnya cara kerja dari pengadilan dan polisi, dalam arti paling luas (diambil dari J orgen J epsen), adalah keseluruhan kebijakan, yang dilakukan melalui perundangundangan dan badan-badan resmi, yang bertujuan untuk menegakkan norma-norma sentral dari masyarakat.

Untuk mendapatkan hasil kajian yang komprehensif, analisis tentang kebijakan kriminal penegakan hukum terhadap tindak pidana memproduksi barang yang tidak memenuhi SNI wajib ini sesuai dengan kewenangan masing-masing lembaga yang terbagi dalam pembagian kekuasaan negara, mulai dari perumusan peraturan perundangundangan oleh kekuasaan membuat undangundang (legislatif), penegakan hukum oleh kekuasaan pemerintahan negara (eksekutif) yang terdiri dari penyelidikan dan penyidikan oleh Penyidik Polri maupun Penyidik PNS hingga penuntutan oleh Penuntut Umum pada Kejaksaan RI, serta kebijakan kriminal kekuasaan kehakiman (yudikatif) yang tercermin dalam putusan-putusan pengadilan atas tindak pidana memproduksi barang yang tidak memenuhi SNI wajib.

Ketentuan tentang Standar Nasional Indonesia (SNI) ini diatur antara lain dalam Undang-Undang RI Nomor 3 Tahun
2014 tentang Perindustrian dan UndangUndang RI Nomor 20 Tahun 2014 tentang Standarisasi dan Penilaian Kesesuaian, dan Peraturan Pemerintah RI Nomor 102 Tahun 2000 tentang Standarisasi Nasional. Pada dasarnya pemberlakuan SNI ini sifatnya adalah sukarela, namun berdasarkan Pasal 52 Ayat (2) Undang-Undang RI Nomor 3 Tahun 2014 tentang Perindustrian, pemerintah dapat menetapkan pemberlakuan SNI secara wajib terhadap barang dan/atau J asa Industri yang telah ditetapkan, yang dilakukan untuk: a. keamanan, kesehatan, dan keselamatan manusia, hewan, dan tumbuhan, b. pelestarian fungsi lingkungan hidup, c. persaingan usaha yang sehat, d. peningkatan daya saing, dan/atau, e. peningkatan efisiensi dan kinerja industri.

Dalam Undang-Undang RI Nomor 20 Tahun 2014 tentang Standarisasi dan Penilaian Kesesuaian juga diatur tentang SNI wajib ini. Dalam Pasal 24 Ayat (1) ditentukan bahwa dalam hal berkaitan dengan kepentingan keselamatan, keamanan, kesehatan, atau pelestarian fungsi lingkungan hidup, kementerian/lembaga pemerintah nonkementerian berwenang menetapkan pemberlakuan SNI secara wajib dengan peraturan menteri atau peraturan kepala lembaga pemerintah nonkementerian. Pembuat undang-undang merumuskan beberapa larangan terkaitstandarisasi industri ini, yang masing-masing diancam dengan sanksi administratif atau sanksi pidana. Sanksi administratif terhadap pelanggaran terhadap larangan sebagaimana tersebut di atas dapat berupa: 1. peringatan tertulis, 2 . denda administrasi, 3. penutupan sementara, 4. pembekuan izin usaha industri, dan/atau 5. pencabutan izin usaha industri.

Sebagai norma hukum yang memuat ketentuan pidana, Pasal 120 Ayat (1) dan Ayat (2) jo. Pasal 53 Ayat (1) huruf b UndangUndang RI Nomor 3 Tahun 2014 tentang Perindustrian memuat rumusan tentang subyek hukum yang menjadi sasaran norma tersebut (addressaat norm), Perbuatan yang dilarang (strafbaar), Ancaman pidana (strafmaat).

Tindak pidana terkait SNI ini dirumuskan sebagai delik commissionis, yaitu delik berupa pelanggaran terhadap suatu larangan dalam undang-undang. Dari sudut sikap batin pelaku dalam melakukan perbuatan yang dilarang, 
pembuatundang-undang merumuskan tindak pidana terkait SNI ini baik sebagai tindak pidana yang dilakukan dengan sengaja (opzettelijke delicten) sebagaimana diatur dalam Pasal 120 Ayat (1) UU No. 3 Tahun 2014 tentang Perindustrian maupun tindak pidana yang dilakukan secara tidak sengaja atau karena kelalaiannya (culpooze delicten) sebagaimana diatur dalam Pasal 120 Ayat (2) UU No. 3 Tahun 2014 tentang Perindustrian.

Bentuk kesengajaan yang dikehendaki oleh pembuat undang-undang dalam hal ini adalah kesengajaan dalam bentuk sengaja dengan maksud, yaitu perbuatan yang diketahui dan dikehendaki oleh pelakunya, sebagaimanapendapat Satochid Kertanegara, kesalahan (schuld) ini adalah merupakan unsur subyektif dari tindak pidana, disamping kemampuan bertanggung jawab (toerekenings vatbaarheid).Untuk membuktikan unsur "dengan sengaja" dalam bentuk "sengaja dengan maksud" ini, P enuntut Umum di persidangan harus membuktikan bahwa pelaku mengetahui dan menghendaki dilakukannya perbuatan tersebut, yaitu 1 . Pelaku mengetahui bahwa tindakannya adalah merupakan perbuatan memproduksi, mengimpor, dan/atau mengedarkan barang dan/atau jasa industry, 2.P elaku mengetahui bahwa barang dan/atau jasa industri yang diproduksi, diimpor, dan/atau diedarkannya tersebut adalah termasuk barang yang wajib SNI, 3.P elaku mengetahui bahwa barang dan/ atau jasa industri yang diproduksi, diimpor, dan atau diedarkannya tersebut tidak atau belum memenuhi SNI, 4.Pelaku menghendaki dilakukannya hal tersebut.

Pelaksanaan pengawasan dan pengendalian terhadap kegiatan usaha industri dan kegiatan usaha kawasan industri dilakukan oleh pejabat dari unit kerja di bawah menteri dan/atau lembaga terakreditasi yang ditunjuk oleh menteri, paling sedikit meliputi pemenuhan dan kepatuhan terhadap peraturan di bidang perindustrian, antara lain SNI, spesifikasi teknis, dan/atau pedoman tata cara.Di dalam Pasal 118 UndangUndang Perindustrian ditentukan bahwa dalam hal pelaksanaan pengawasan dan pengendalian tersebut ditemukan dugaan terjadi tindak pidana, pejabat atau lembaga sebagaimana tersebut di atas melapor kepada Penyidik Pegawai Negeri Sipil (PPNS) di bidang perindustrian.PPNS
Perindustrian memberitahukan dimulainya penyidikan, melaporkan hasil penyidikan, dan memberitahukan penghentian penyidikan kepada penuntut umum melalui pejabat Polri, dan dalam melaksanakan penyidikan, PPNS Perindustrian dapat meminta bantuan kepada aparat penegak hukum.

Pembuat undang-undang tidak mengatur kaitan antara standarisasi industri dengan penguatan sektor usaha kecil dan menengah, dan juga tidak ditentukan apakah penegakan hukum pidana tersebut bersifat ultimum remedium ataukah premium remedium.

Kebijakan Kriminal Penyelidikan, Penyidikan dan Penuntutan terhadap tindak pidana yang melanggar ketentuan SNI wajib secara kelembagaan, Polri belum memiliki peraturan/kebijakan internal yang bersifat khusus untuk penegakan hukum terhadap tindak pidana yang melanggar ketentuan SNI wajib. Di Kejaksaan RI, Penulis tidak menemukan adanya kebijakan kriminal yang khusus berkaitan dengan penegakan hukum terhadap tindak pidana yang melanggar ketentuan SNI wajib. Dari beberapa perkara yang dicontohkan di atas dan dari hasil wawancara dengan Kasipidum Kejaksaan Karanganyar, dapat dilihat bahwa penuntut umum hanya menjalankan criminal procedure dan melakukan penegakan hukum terhadap tindak pidana yang melanggar ketentuan S N I wajib ini sebagai business as usual.

Teorema Coase memberikan gambaran ide-ide sentral analisis hukum dan ekonomi, dengan mencontohkan bagaimana mencari solusi yang efisien terhadap pabrik yang yang mengeluarkan asap dan menyebabkan kerusakan cucian digantung di luar ruangan. A pabila di tingkat penyidik maupun penuntutan mengambil kebijakan kriminal dengan mengacu pada Teorema Coase, tindak pidana yang melanggar ketentuan SNI wajib bisa diselesaikan ditingkat penyidik dan penuntutan.

Mahkamah Agung RI tidak menerbitkan suatu aturan tertentu tentang penanganan perkara-perkara terkait SNI wajib ini, Penulis juga tidak menemukan adanya hasil Rapat Kamar Pidana Mahkamah Agung maupun hasil Rapat Kerja Nasional Mahkamah Agung RI yang membahas permasalahan ini, demikian pula belum ada putusan yang menjadi yurisprudensi ataupun landmark 
decision, karenanya Penulis mengkaji kebijakan kriminal penegakan hukum di tingkat pemeriksaan persidangan langsung dari beberapa putusan-putusan yang telah dijatuhkan dalam tindak pidana terkait SNI wajib ini, karena memang belum banyak perkara terkait SNI wajib yang sampai diajukan ke pengadilan.

Sebagai contoh putusan atas tindak pidana yang berkaitan dengan SNI wajib adalah Putusan Pengadilan Negeri Karanganyar Nomor 169/P id.S us/2015/P N Krg, Tanggal 23 Desember 2015 atas nama Terdakwa Muhammad Kusrin bin Amri yang menjatuhkan putusan pemidanaan berupa pidana bersyarat dan pidana denda terhadap Terdakwa.Terhadap putusan Pengadilan Negeri Karanganyar yang menjatuhkan secara kumulatif antara pidana bersyarat dengan pidana denda, Penulis berpendapat putusan tersebut tidak melanggar ketentuan ancaman pidana kumulatif, karena ketentuan pidana bersyarat adalah ketentuan umum dalam KUHP yang juga berlaku bagi semua tindak pidana, termasuk tindak pidana yang diatur dalam undang-undang khusus di luar KUHP, kecuali undang-undang tersebut menentukan lain.Dalam kasus posisi demikian, Penulis sependapat dengan Putusan Pengadilan Negeri Karanganyar tersebutyang menjatuhkan pidana bersyarat, karena sebenarnya usaha Terdakwa adalah termasuk Usaha Mikro, Kecil, dan Menengah (UMKM) yang memiliki potensi untuk dikembangkan, dan memenjarakan Terdakwa akan lebih banyak menimbulkan kerugian dari pada manfaatnya. Karyawan Terdakwa akan kehilangan pekerjaan dan Terdakwa akan kehilangan kesempatan untuk berpartisipasi dalam pekerjaan-pekerjaan, yang secara ekonomis menguntungkan masyarakat dan keluarganya, dan alasan-alasan la in sesuai dengan pendapat Muladi. Berkaitan dengan penjatuhan pidana denda secara kumulatif adalah untuk memperberat penjatuhan pidana.Pidana denda yang dijatuhkan haruslah proporsional dengan antara tingkat kesalahan, keuntungan yang diperoleh, dan tingkat kemungkinan dapat terungkapnya tindak pidana tersebut, dengan kemampuan ekonomi terdakwa.Hal ini yang menjadi inti ajaran utiliarian.Pengaturan tentang pelaksanaan pidana denda dengan cara mencicil/mengangsur ini juga telah diterapkan di Belanda, sebagaimana dikatakan oleh Remmelink, bahwa jika dalam vonis dijatuhkan satu atau lebih denda sampai mencapai jumlah sekurang-kurangnya 500 guilder, maka hakim berwenang untuk menetapkan dalam putusannya bahwa terpidana diperkenankan melunasi denda dengan cara mencicil. Setiap cicilan sekurang-kurangnya harus senilai 100 guilder. Hakim akan sekaligus menetapkan jangka waktu dari cicilan kedua dan berikutnya.

Mengenai status barang bukti diatur dalam Pasal 194 Kitab Undang-Undang Hukum Pidana, yang menjelaskan bahwa dalam putusan pidana baik berupa putusan pemidanaan, bebas, atau lepas dari segala tuntutan hukum, pengadilan menetapkan status dari barang bukti yang diajukan ke persidangan. P enentuan status barang bukti tersebut da pat berupa : 1. Diserahkan kepada pihak yang paling berhak menerima kembali yang namanya tercantum dalam putusan tersebut, 2. Dirampas untuk kepentingan negara, atau 3. Dimusnahkan atau dirusak sehingga tidak dapat dipergunakan lagi.

Diluar ketentuan tersebut, barang bukti dapat pula ditetapkan untuk dipergunakan untuk dipergunakan dalam pembuktian perkara lain apabila masih diperlukan (Pasal 46 Ayat (2) KUHAP).

Dalam Undang-Undang Perindustrian tidak ada pengaturan lain tentang ketentuan status barang bukti produk dalam tindak pidana yang melanggar ketentuan tentang S N I wajib ini. Ketentuan tentang status barang bukti dalam perkara yang melanggar ketentuan $\mathrm{SNI}$ wajib baru diatur dalam peraturan-peraturan menteri yang memberlakukan SNI wajib.

Dalam Putusan Pengadilan Negeri Karanganyar Nomor 169/P id.Sus/2015/PN $\mathrm{Krg}$, barang bukti produk berupa televisi tabung yang siap edar ditetapkan untuk dirampas untuk dimusnahkan, sedangkan barang bukti berupa alat-alat perakitan dan komponen-komponen televisi ditetapkan untuk dikembalikan kepada Terdakwa.Untuk barang bukti produk berupa pupuk dan TV tabung yang diproduksi tidak memenuhi S NI jelas secara imperatif diatur harus dirampas untuk dimusnahkan.

Banyak kalangan yang berpendapat sebaiknya barang bukti tersebut tidak dimusnahkan, tetapi dimanfaatkan saja atau 
lebih baik disumbangkan karena memiliki nilai ekonomis, sebagaimana pendapat seorang terdakwa sendiri yang menyayangkan hasil produksinya dimusnahkan. Namun pemusnahan barang bukti tersebut sudah tepat, karena suatu produk ditetapkan wajib $\mathrm{SNI}$ atas dasar pertimbangan keamanan, kesehatan, dan keselamatan manusia, hewan, dan tumbuhan, pelestarian fungsi lingkungan hidup, persaingan usaha yang sehat, peningkatan daya saing, dan/atau, peningkatan efisiensi dan kinerja industri, jadi diproduksi, diimpor, dan diedarkannya produk yang tidak memenuhi SNI tersebut tentu bertentangan dengan alasan dan tujuan diberlakukannya SNI wajib.

2. Efisiensi Penegakan Hukum Terhadap Tindak Pidana Perindustrian Dalam Mewujudkan Kesejahteraan Masyarakat.

Lamintang berpendapat bahwa adanya penderitaan-penderitaan yang bersifat khusus itu telah menyebabkan hukum pidana mendapatkan tempat tersendiri di antara hukum lainnya, yang menurut pendapat para sarjana, hukum pidana itu hendaknya dipandang sebagai suatu ultimum remedium atau sebagai suatu upaya yang harus dipergunakan sebagai upaya terakhir untuk memperbaiki kelakuan manusia, dan wajarlah apabila orang menghendaki agar hukum pidana itu dalam penerapannya haruslah disertai dengan pembatasan-pembatasan yang seketat mungkin.

Sebagai sebuah asas, ultimum remedium ini tidak ditemukan dalam ketentuan umum KUHP seperti halnya asas legalitas yang tercantum dalam Pasal 1 KUHP.Istilah otentik Ultimum remedium baru dapat ditemukan dalam Penjelasan Umum Angka 6 UndangUndang RI Nomor 32 Tahun 2009 tentang Perlindungan dan Pengelolaan Lingkungan Hidup (PPLH). Istilah ultimum remedium ini tidak ditemukan dalam Undang-Undang Perindustrian, namun demikian hal itu tidak lantas menjadikan asas ultimum remedium tidak berlaku dalam tindak pidana perindustrian, khususnya yang berkaitan dengan SNI wajib ini.

Dalam konteks penegakan hukum terhadap tindak pidana perindustrian yang berkaitan dengan SNI wajib, khususnya yang dilakukan oleh pelaku Usaha Mikro Kecil dan Menengah (UMKM), banyak pihak menyayangkan penegakan hukum oleh aparat yang lebih mengedepankan pendekatan pidana.Untuk membahas masalah ini, tentunya harus dilihat kembali tujuan perindustrian itu sendiri yang diatur dalam Pasal 3 Undang-Undang RI Nomor 3 Tahun 2014 tentang Perindustrian. Penulis berpendapat, penegak hukum di semua tingkat pemeriksaan harus melihat permasalahan hukum secara menyeluruh, karena hukum tidak berdiri sendiri melainkan juga berkaitan dengan bidang lain seperti ekonomi, sosial, dan budaya, yang kesemuanya harus dikembalikan pada apa yang menjadi tujuan kita dalam bernegara. Demikian pula dalam masalah tindak pidana yang berkaitan dengan SNI wajib ini.Badan Standar Nasional (BSN) menekankan pentingnya mengedepankan unsur pembinaan terlebih dahulu sebelum dilakukan tindakan terkait penerapan SNI pada pelaku Usaha Mikro Kecil dan Menengah (UMKM), SNI wajib diterapkan di era Masyarakat Ekonomi ASEAN (MEA). Tanpa SNI, pasar produk lokal yang tidak memiliki daya saing akan tergilas oleh produk dariASEAN yang jauh lebih kompetitif. Melalui pembinaan kepada pelaku usaha, tujuan dari SNI lebih efektif.

Dalam perkara atas nama Terdakwa Muhammad Kusrin dalam Putusan Pengadilan Negeri Karanganyar sebagaimana tersebut di atas, ternyata terdakwa telah berusaha memenuhi kewajiban $\mathrm{SNI}$ atas produk televisi CRT nya, namun ia tidak mendapatkan informasi dan bantuan yang memadai dari pemerintah sendiri untuk pengurusan sertifikasinya. Baru setelah ekspose pemusnahan barang bukti, pemerintah tergerak untuk memfasilitasi terbitnya SNI wajib atas produk televisi CRT Muhammad Kus rin, setelah dilakukan beberapa pengujian dan penyesuaian atas produknya.Namun Terdakwa tetap dipersalahkan, sesuai asas bahwa setiap orang dianggap tahu tentang hukum yang telah diundangkan.J ika penegak hukum hanya sekedar menegakan undang-undang, permasalahan pelanggaranpelanggaran di atas dapat dengan mudah dikatakan sebagai pelanggaran hukum. Namun jika dilihat secara menyeluruh, dari sudut tujuan perindustrian menurut undangundang, apalagi dari sudut konstitusi tentang tujuan bernegara, dan juga Instruksi P residen Nomor 11 Tahun 2011 tentang Pelaksanaan Komitmen Cetak Biru Masyarakat Ekonomi 
Association of Soultheast Asian Nations Tahun 2011 dan langkah-langkah yang telah dilakukan berdasarkan rencana stategis pemerintah dalam rangka menghadapi MEA, Penyidik Polri/PPNS, Penuntut Umum, dan Hakim dapat menggunakan kewenangan diskresinya masing-masing untuk menyikapi perkara-perkara demikian.Sebagaimana disampaikan oleh Eva Achjani Zulfa dan Indrianto Seno Aji di atas, bahwa sebagian penulis berpendapat ultimum remidium dapat pula diterapkan oleh penegak hukum sesuai dengan kewenangan diskresinya masing-masing. Bukan hanya polisi yang memiliki kewenangan diskresi untuk menindaklanjuti atau tidak menindaklanjuti suatu perkara, namun Penuntut Umum juga memiliki kewenangan diskresi yang dikenal sebagai hak oportunitas, yaitu hak untuk mengesampingkan suatu perkara untuk kepentingan umum, termasuk pula kewenangan untuk penggabungan maupun pemisahan perkara (Pasal 141 dan Pasal 142 KUHAP). KUHAP menganut sistem diferensi fungsional, yaitu pembedaan fungsi dari masing-masing tingkat pemeriksaan/ penegakan hukum.

Terhadap fungsi ultimum remedium dari hukum pidana, menurut teori economic analysis of law, lembaga penegakan hukum harus mempertimbangkan upaya meminimalisir biaya dalam penegakan hukum. Baik biaya yang mungkin timbul akibat kesalahan putusan hakim (erroneous judicial decisions) maupun biaya untuk menjalankan sistem prosedur itu sendiri (cost of operating procedural syystem).Dalam tindak pidana perindustrian, sifat ketentuan yang demikian walaupun tidak diatur oleh pembuat undangundang, dapat diterapkan oleh penegak hukum sesuai dengan kewenangan diskresinya masing-masing, untuk tidak melakukan penindakan (khususnya terhadap pelaku UMKM) sebelum negara memberikan bantuan terhadap mereka.Menurut Penulis begitulah seharusnya fungsi ultimum remedium digunakan dengan menggunakan pilihan model penegakan hukum untuk memaksimalkan kesejahteraan sosial.

Pelanggaran ketentuan SNI wajib ini, sepanjang produsen, importir, ataupun distributor/pedagang yang memproduksi, mengimpor, atau mengedarkan barang dan/ atau jasa industri tidak dapat menunjukan
Sertifikat Produk Penggunaan Tanda (SPPT) $\mathrm{SNI}$ atas produknya, maka mereka telah terbukti melanggar hukum, karena memang begitulah das sollen nya, hukum positifnya. Bagaimana dengan das seinnya, apa yang ingin kita capai dalam penegakan hukum terhadap perkara perindustrian ini.Untuk mewujudkan tujuan perindustrian yang diantaranya adalah untuk mewujudkan industri nasional sebagai pilar dan penggerak perekonomian nasional, mewujudkan industri yang mandiri, berdaya saing, dan maju, membuka kesempatan berusaha dan perluasan kesempatan kerja, serta meningkatkan kemakmuran dan kesejahteraan masyarakat secara berkeadilan - yang dalam economic analysis of law disebut sebagai memaksimalkan kesejahteraan sosial - seharusnya tersangka atau terdakwa diberi kesempatan untuk membuktikan bahwa sebenarnya barang dan/atau jasa industrinya itu telah memenuhi standar, hanya saja belum mendapat sertifikat SNI misalnya karena tidak paham cara pengurusannya, tidak memiliki sumber dana yang cukup untuk mengajukan sertifikasi, lalai mensertifikasi produk yang merupakan pengembangan, variasi, atau perubahan bentuk dari produk sebelumnya, atau karena sebab-sebab lainnya yang menurut akal sehat dapat dinilai beralasan.Di persidangan hakim dihadapkan pada pilihan apakah akan menerapkan begitu saja pemidanaan atas tidak dapat ditunjukannya SPPT SNI oleh terdakwa atau memberikan kesempatan dan mempertimbangkan pembuktian bagi terdakwa untuk membuktikan bahwa sebenamya barang dan/atau jasa industrinya memenuhi SNI.

Untuk mengatasi hal demikian, Posner mencontohkan bagaimana Federal Rule of Evidence No. 403 (Peraturan Pemerintah Federal Amerika Serikat tentang Alat Bukti) memberikan arahan bagi hakim dalam menentukan apakah suatu alat bukti tertentu dapat diterima di persidangan dan dipertimbangkan memiliki nilai pembuktian. Hakim harus mempertimbangkan antara kecenderungan alat bukti tersebut dapat mendukung keakuratan materi pembuktian yang menghindari bahaya praduga tidak fair, penyesatan isu, dan kekeliruan penilaian para juri dengan pertimbangan tentang penundaan sidang yang tidak layak dan membuang waktu, atau ketidakperluan memperhatikan 
bukti yang diajukan secara kumulatif (sudah terbukti dari alat bukti la innya). Disitu hakim menerapkan pertimbangan antara high administrative cost dengan low-error reduction (and perhaps high error promotion).

Diskresi hakim yang demikian tentu sebaiknya tidak diterapkan untuk semua perkara SNI wajib. Hal ini sejalan dengan apa yang dikatakan oleh mantan Ketua MA Subekti, bahwa "Pengadilan yang menyingkirkan ("wegtoetsen") suatu ketentuan undang-undang harus merupakan suatu peristiwa yang luar biasa, tidak boleh merupakan suatu kejadian yang sehari-hari. Pekerjaan pengadilan adalah mengetrapkan undang-undang dan apa yang dilakukannya dalam keadaan darurat tadi harus terbatas pada melakukan "tambal-sulam" pula, sedangkan perombakan wajib dilakukan oleh pembuat undang-undang".Dalam konteks perkara SNI wajib ini, kekecualian demikian dapat diberikan kepada terdakwa yang berasal dari kalangan pelaku UMKM, karena pembinaan UMKM adalah juga merupakan kewajiban negara (pemerintah). Apabila pihak terdakwa dapat membuktikan pembuktian yang dibebankan kepadanya tersebut, hakim dapat mempertimbangkannya sebagai pertimbangan untuk membebaskan terdakwa dari dakwaan, karena secara materil barang dan/atau jasa industri terdakwa telah memenuhi S NI, walaupun pada saatpenegak hukum melakukan pemeriksaan pertama kali memang benar barang dan/atau jasa industri terdakwa tersebut belum dilengkapi sertifikat SNI.

Undang-undang RI Nomor 3 Tahun 2014 tentang Perindustrian memuat ancaman pidana atas tindak pidana yang melanggar ketentuan SNI wajib dengan ancaman pidana yang bersifat kumulatif, yaitu pidana penjara dan pidana denda dengan ketentuan pidana maksimum khusus, tanpa adanya pidana minimum khusus.Di luar ketentuan pidana tersebut, maka berlaku ketentuan umum dalam Kitab Undang-undang Hukum Pidana (KUHP), bahwa pidana penjara selama waktu tertentu paling singkat adalah 1 (satu) hari, dan denda paling sedikit adalah Rp. 3,75 (tiga rupiah tujuh puluh lima sen). Mengenai batasan pidana denda ini, pembuat undangundang tidak pernah membuat ketentuan yang menyesuaikan perkembangan, padahal nilai uang sudah sangat jauh berbeda.Mahkamah
Agung RI dengan Peraturan Mahkamah Agung (Perma) Nomor 2 Tahun 2012, telah membuat pengaturan yang menyesuaikan batasan tindak pidana ringan dan ancaman pidana denda dalam KUHP.Namun Perma tersebut hanya memuat pengaturan yang menyesuaikan jumlah maksimum hukuman denda yang diancamkan dalam KUHP, tetapi tidak mengatur tentang penyesuaian denda minimum umum (Pasal 30 Ayat (1) KUHP). Hakim dapatmenggunakan kewenangannya untuk memberikan penafsiran sistematis, bahwa penyesuaian pidana denda tersebut juga dapat diberlakukan terhadap pidana denda minimum umum, yaitu dilipatgandakan menjadi 1.000 (seribu) kali, sehingga batasan pidana denda minimum umum menjadi $\mathrm{Rp}$. $3,75 \times \mathrm{Rp} .1 .000,00$ (seribu rupiah) $=\mathrm{Rp}$. $3.750,00$ (tiga ribu tujuh ratus lima puluh rupiah).

Undang-undang Perindustrian tidak mengatur tentang penyitaan dan perampasan aset agar denda dibayarkan oleh terpidana, sehingga instrumen pemaksanya adalah kembali pada ketentuan Pasal 30 Ayat (2) dan Ayat (3) KUHP, bahwa jika denda tidak dibayar, lalu diganti dengan kurungan yang lamanya paling sedikit 1 (satu) hari dan paling lama 6 (enam) bulan. Dimana ketentuan tersebut dikecualikan jika ada pemberatan denda disebabkan karena perbarengan (concursus) atau pengulangan (recidive) atau karena ketentuan Pasal 52 dan Pasal 52 a KUHP, maka kurungan pengganti paling lama dapat menjadi 8 (delapan) bulan dan sekali-kali tidak boleh melebihi 8 (delapan) bulan (Pasal 30 Ayat (5) dan Ayat (6) KUHP).

Menurut teori Economic Analysis of Law, pidana yang dapat diterapkan terhadap pelaku tindak pidana haruslah bervariasi, hal ini agar dapat menyesuaikan dengan tujuan pemidanaan.Karena sifat pemidanaan adalah individual, maka tidak ada satu pemidanaan yang tepat untuk diterapkan terhadap semua pelaku tindak pidana. Walaupun untuk tindak pidana yang sejenis, dimana perbuatan dan akibat yang ditimbulkannya hampir sama. Hakim tetap harus memperhatikan disparitas putusan agar tidak terjadi kesenjangan antara satu terpidana dengan yang lainnya.Mengenai pertimbangan terhadap masing-masing jenis pemidanaan, menurut teori Economic Analysis of Law, bahwa pada intinya pidana penjara memerlukan biaya sosial yang 
tidak sedikit, yang harus ditanggung oleh negara dimana dananya diperoleh dari pajak masyarakat.Artinya masyarakat yang telah menjadi korban dari tindak pidana, harus membiayai tidak hanya criminal procedurenya, tetapi juga pemidanaannya.Inilah yang menyebabkan pidana penjara dalam waktu yang relatif lebih singkat lebih diinginkan (preferable).

Pidana penjara dalam waktu relatif singkat ini ternyata juga memiliki permasalahannya sendiri. Menurut hasil penelitian Niniek Suparni, pidana penjara khususnya dalam jangka pendek, akan menghambat usaha pembinaan terhadap terpidana, selain itu hanya akan memberikan kesempatan kepada terpidana selama dalam rumah tahanan negara atau lembaga pemasyarakatan untuk berguru kepada penjahat profesional, sehingga setelah menjalani pidananya justeru menjadi lebih jahat. P ilihan selanjutnya adalah pidana denda.U paya paksa dari pidana denda tersebut adalah adanya pidana kurungan pengganti denda.Sekalipun hakim memiliki kewajiban untuk memperhatikan kemampuan terdakwa secara proporsional dengan perbuatan dan akibat yang ditimbulkannya, dalam praktik terdapat juga kemungkinan dimana seorang terpidana lebih memilih untuk menjalani saja pidana kurungan pengganti daripada harus membayar denda.Hal demikian terjadi juga dengan pertimbangan ekonomis, dimana terpidana sebagai pelaku yang rasional akanmemperhitungkan besaran denda yang harus ia bayar dibanding dengan yang dapat ia hasilkan selama ia menjalani kurungan pengganti dendanya.

Dalam perkara SNI wajib ini, pidana denda maksimal Rp. 1.000.000.000,00 untuk kelalaian dan maksimal R p. 3.000.000.000,00 untuk kesengajaan. Sementara pidana kurungan pengganti paling lama adalah 6 (enam) bulan dan dapat diperberat hingga 8 (delapan) bulan. Terpidana akan mempertimbangkan berapa lama waktu yang ia perlukan untuk menghasilkan sejumlah denda tersebut, jika penghasilannya selama sampai dengan 6 (enam) atau 8 (delapan) bulan tidak mencapai sekian atau bahkan jauh di bawahnya, terpidana dapat memilih menjalani saja pidana kurungan pengganti. J ika terjadi keadaan demikian, maka tujuan dari dijatuhkannya pidana denda menjadi tidak tercapai.Mengenai hal tersebut, RUU
KUHP Tahun 2010 sudah memberikan solusinya, agar tujuan dari pidana denda dapat tercapai, dan terhadap terpidana terlebih dahulu diupayakan membayar dendanya, ditentukan adanya ketentuan pembayaran dengan cara mencicill dalam jangka waktu sesuai putusan hakim, jika pidana denda tidak dibayar penuh dalam jangka waktu yang ditetapkan, maka diambil dari kekayaan atau pendapatan terpidana untuk pemenuhan pidana dendanya. J ika dari kekayaan atau pendapatan yang diambil juga tidak terpenuhi, baru dikenakan pidana pengganti denda.

Kemungkinan lainnya adalah pidana kombinasi antara pidana denda dan pidana penjara.Dalam kacamata Teori Economic Analysis of Law, Poin utama di sini adalah denda yang dikenakan harus pada tingkat maksimum yang layak sebelum memilih pidana penjara. Dengan kata lain, penjatuhan pidana penjara yang dipaksakan tidak optimal kecuali pidana denda yang diterapkan telah maksimal (pidana denda yang maksimal dapat diinterpretasikan sebagai tingkat kemakmuran seorang individu).Dengan demikian efek deteren yang dihasilkan tetap, namun biaya yang digunakan untuk pelaksanaan pidana penjara bisa jauh berkurang dan dapat digunakan untuk peningkatan kesejahteraan masyarakat.Diluar pilihan-pilihan ters ebut, agar lebih fleksibel dan memberikan pilihan yang lebih banyak pada hakim dalam menjatuhkan putusan sebaiknya pidana denda dan pidana penjara dirumuskan secara alternatif-kumulatif dengan kata penghubung "dan/atau", sehingga hakim dapat secara kasuistis menentukan pidana yang tepat apakah pidana penjara saja, pidana denda saja, atau pidana denda dan pidana penjara secara kumulatif.Disamping itu, terdapat juga pilihan pidana percobaan sebagaimana diatur dalam Pasal 14 a sampai dengan 14C KUHP.Walaupun dalam Pasal 14 c Ayat (1) KUHP ditentukan bahwa dalam perintah yang dimaksud Pasal 14 a, kecuali jika dijatuhkan pidana denda, selain menetapkan syarat umum bahwa terpidana tidak akan melakukan tindak pidana, Hakim dapat menetapkan syarat khusus bahwa terpidana dalam waktu tertentu yang lebih pendek dari masa percobaannya, harus mengganti segala atau sebagian kerugian yang ditimbulkan oleh tindak pidana, semuanya atau sebagiannya 
saja, yang akan ditentukan pada perintah itu dalam waktu yang akan ditentukan pada perintah itu juga, yang kurang daripada masa percobaan.

Walaupun dalam perkara SNI wajib, hakim menjatuhkan pidana denda, hakim tetap dapat menjatuhkan pidana percobaan dengan dua alasan, pertama karena ancaman pidana dalam Undang-undang Perindustrian disusun secara kumulatif, dan kedua karena Undang-undang Perindustrian merupakan ketentuan khusus, sehingga berlaku asas lex spesialis derogate legi generale.Dengan bervariasinya pilihan ancaman pidana yang dapat dijatuhkan oleh hakim, memberikan keleluasaan yang lebih bagi hakim untuk menentukan jenis pidana apa yang tepat dijatuhkan sesuai dengan karakteristik masing-masing pelaku dan perbuatannya.

\section{Simpulan}

1. Tidak ada Kebijakan kriminal khusus dalam penegakan hukum terhadap tindak pidana yang melanggar ketentuan S NI wajib di tingkat penyidikan dan penuntutan yang dilaksanakan oleh PPNS, Penyidik Polri, dan Penuntut U mum pada Kejaksaan RI sebagai kekuasaan pemerintahan negara (eksekutif). Sekalipun ada beberapa kebijakan yang mendukung penegakan hukum terkait SNI wajib, hal itu masih ditujukan dalam rangka menjalankan tugas pokok dan fungsi penyidik dan penuntut umum secara umum, belum dikaitkan dengan tujuan perindustrian itu sendiri.Begitu juga di tingkat kekuasaan kehakiman yang dijalankan oleh Mahkamah Agung RI dan badan peradilan di bawahnya, tercermin dari putusan-putusan yang dijatuhkan atas tindak pidana yang melanggar ketentuan S NI wajib.

2. Penegakan hukum terhadap tindak pidana yang melanggar ketentuan SNI wajib belum efisien untuk mewujudkan kesejahteraan masyarakat karena belum mengedepankan fungsi ultimum remedium hukum pidana, penerapan pembuktian secara materiil atas barang dan/atau jasa yang diberlakukan S NI wajib dan penjatuhan pidana yang optimal.

\section{E. Saran}

1. Dalam menjalankan penegakan hukum terhadap tindak pidana yang melanggar ketentuan SNI, penegak hukum sebaiknya menjalankan fungsi ultimum remedium dari hukum pidana dalam menangani kasus-kasus berkaitan SNI wajib ini. Khususnya terhadap pelaku UMKM sebaiknya mengedepankan pembinaan daripada penindakan, Khusus terhadap pelaku UMKM, di persidangan dapat diberi kesempatan untuk secara materil membuktikan bahwa barang dan/atau jasa industrinya sebenarnya telah memenuhi SNI, Untuk penjatuhan pidana yang optimal, diharapkan hakim mempertimbangkan faktor kesejahteraan masyarakat, dengan memilih jenis pidana apa yang efisien dan produktif untuk di jalankan.

2. Rumusan ancaman pidana atas tindak pidana yang melanggar ketentuan SNI wajib sebaiknya dibuat alternatif-kumulatif antara pidana penjara dan pidana denda dengan rumusan pidana penjara paling lama ... tahun "dan/atau" pidana denda paling banyak R p.....

\section{Daftar Pustaka}

Barda Nawawi Arief, 1996, Bunga Rampai Kebijakan Hukum Pidana, PT. Citra Aditya Bakti, Bandung, 1996.

Dana Aditiasari, Kisah Kusrin PembuatTV, Hasil Kerja 4 Tahun Habis Dalam 5 Menit, http://finance.detik. com/read/2016/01/19/120932/3121748/1036/kisah- kusrin-pembuat-tv-hasil-kerja-4-tahun-habisdalam-5-menit, diakses pada tanggal 19 J anuari 2016.

Eva Ahjani Zulfa dan Indriyanto Seno Aji. 2011.Pergeseran Paradigma Pemidanaan, Bandung: Lubuk Agung, Cetakan I.

Ikahi, November 2014, Varia Peradilan Majalah Hukum, Tahun XXX No. 348.

J an Remmelink. 2003. Hukum Pidana, Komentar atas Pasal-pasal Terpenting dari KUHP Belanda dan Padanannya dalam KUHP Indonesia (Inleiding tot de Studie van het Nederlande Strafrecht), 
diterjemahkan oleh Tristam Pascal Moeliono. J akarta: PT. G ramedia Pustaka Utama.

Louis Kaplow dan Steven Shavell, "E conomic Analysis of Law" dalam A.J . Auherbach dan M. Feldstein, eds. Handbook of Public E conomics, Volume 3, (Elsevier Science: 2002).

Mahkamah Agung RI, Peraturan Mahkamah Agung Nomor 2 Tahun 2012 tentang Penyesuaian Batasan Tindak P idana Ringan dan J umlah Denda Dalam KUHP.

Muladi. 1985.Lembaga Pidana Bersyarat, Bandung: Penerbit Alumni.

Niniek Suparni.2007.Eksistensi Pidana Denda dalam Sistem Pidana dan Pemidanaan, Ed. 1., Cet. 1. Jakarta: Sinar Grafika.

Neneng Zubaidah, Hindari Tergerus Pasar Bebas ASEAN, Usaha Kecil Wajib SNI, http://ekbis.sindonews. com/read/1077994/34/hindari--tergerus-pasar-bebas-asean-usaha-kecil-wajib-sni-145303349, diakses pada tanggal $18 \mathrm{~J}$ anuari 2016.

P.A.F. Lamintang, 1997, Dasar-Dasar Hukum Pidana Indonesia, PT. Citra Aditya Bakti, Bandung.

Posner sebagaimana dikutip oleh Donald H.J . Hermann, "Review of Economic Analisys of Law By Richard A. Posner", Washington University Law Review, Volume 1974, Issue 2.

Presiden Republik Indonesia, Instruksi Presiden RI tentang Pelaksanaan Komitmen Cetak Biru Masyarakat Ekonomi Association of Southeast Asian Nations Tahun 2011, Nomor 11 Tahun 2011,

Prof. Hari Chand, Modern J urisprudence, 1994, international law book services, Malaysia.

Putusan Pengadilan Negeri Karanganyar Nomor 169/P id.S us/2015/P N.Krg, diucapkan pada 23 Desember 2015.

Rancangan Undang-Undang tentang Kitab Undang-Undang Hukum Pidana Tahun 2010 yang diajukan oleh Pemerintah RI ke DPR.

Republik Indonesia, Undang-Undang Dasar Negara Republik Indonesia, Tahun 1945.

Republik Indonesia, Undang-undang Nomor 8 Tahun 1981 tentang Hukum Acara Pidana (KUHAP).

Republik Indonesia, Undang-Undang Nomr 1 Tahun 1946 tentang Hukum Pidana, yang diberlakukan dengan Undang-Undang Nomor 73 Tahun 1958. KUHP terjemahan resmi oleh Tim Penerjemah Badan Pembinaan Hukum Nasional Departemen Kehakiman, Cetakan Kedua, Jakarta: Sinar Harapan, 1985.

Republik Indonesia, Undang-Undang Nomor 3 Tahun 2014 tentang Perindustrian, LN Nomor 4 Tahun 2014.

Richard A. Posner. 1998. Economic Analysis Of Law, Edisi Kelima, Aspen Law \& Business A Division Of Aspen Publishers, New York.

Satochid Kertanegara, Hukum Pidana, Bagian Satu, J akarta: Balai Lektur Mahasiswa.

Setiono, 2005, Pemahaman Terhadap Metodologi Penelitian Hukum, Program Pascasarjana UNS, Surakarta.

Subekti. 1984.Pembinaan Hukum Perdata Nasional oleh Yurisprudensi Indonesia, Dalam Sumbangsih Untuk Prof. Djokosoetono, S.H., J akarta: Penerbit Fakultas Ekonomi Universitas Indonesia. 